\title{
THE EFFECT OF DEPOT MEDROXYPROGESTERONE ACETATE ADMINISTRATION ON THE LEVELS OF FOLLICLE-STIMULATING HORMONE, PROGESTERONE, ESTRADIOL, AND CALCIUM
}

\author{
NURELILASARI SIREGAR ${ }^{1 *}$, RAUZA SUKMA RITA $^{2}$, YUSRAWATI $^{3}$
}

${ }^{1}$ Programme Magister Midwifery, Faculty of Medicine, Andalas University, Padang, Indonesia. ${ }^{2}$ Department of Biochemistry, Faculty of Medicine, Andalas University, Padang, Indonesia. ${ }^{3}$ Department of Obstetrics and Gynaecology, Faculty of Medicine, Andalas University, Padang, Indonesia. Email: elila2103@gmail.com

Received: 04 August 2018, Revised and Accepted: 26 October 2018

ABSTRACT

Objective: The purpose of this research is to determine the effect of depot medroxyprogesterone acetate (DMPA) on the levels of follicle-stimulating hormone (FSH), progesterone, estradiol, and calcium.

Methods: This was a cross-sectional study, this study was conducted in the region of Lubuk Buaya Health Care and Andalas Health Care on SeptemberNovember 2017. Examination of FSH, progesterone, and estradiol levels was performed in the Laboratory Biomedicine, Faculty of Medicine, Andalas University by ELISA method, and the examination of calcium level was performed in Laboratory Biochemistry, Faculty of Medicine, Andalas University by calcium Arsenazo method. Then, the data were analyzed by Kolmogorov-Smirnov and independent $t$-test.

Results: This study showed that there was a significant difference of FSH, progesterone, estradiol, and calcium levels on KB DMPA acceptors and nonacceptors with $\mathrm{p}<0.05$.

Conclusion: The use of contraception DMPA has the effect on the levels of FSH, progesterone, estradiol, and calcium in the blood.

Keywords: Depot medroxyprogesterone acetate, Progesterone, Estradiol, Calcium.

(C) 2019 The Authors. Published by Innovare Academic Sciences Pvt Ltd. This is an open access article under the CC BY license (http://creativecommons. org/licenses/by/4. 0/) DOI: http://dx.doi.org/10.22159/ajpcr.2019.v12i1.28895

\section{INTRODUCTION}

Indonesia is the fourth most populous country in the world with annual population growth rate of $1.38 \%$. By 2020 , it was estimated that the population would be increased by 32.6 million so it would be affect maternal mortality $[3,5]$.

Contraception in terms of health is an attempt to reduce maternal mortality and morbidity by controlling the rate of population growth so as to improve maternal and child health [12].

Depot medroxyprogesterone acetate as a contraceptive in an aqueous suspension injection is given by intramuscular for prolonged action. It was given at a dose of $150 \mathrm{mg}$ every 12 weeks [11]

Substances major metabolite of depot medroxyprogesterone acetate (DMPA) is $6 \alpha$-methyl-6 $\beta, 17 \alpha, 21$-trihydroxy-4-pregnene-3, 20-dione17-acetate which secreted through urine. Approximately 90-95\% DMPA binds to protein, namely albumin, and is metabolized in the liver. DMPA will be conjugated with glucuronic acid and sulfate which is excreted through urine. After DMPA was injected intramuscularly, the MPA is slowly released from the injection site from the low level to persistently enter the circulation and can be detected in the serum after 30 min of injection [20].

The use of hormonal contraceptives such as DMPA could affect the gonadotropin hormone ( $\mathrm{GnRH}$ ) produced in the hypothalamus, thereby suppressing luteinizing hormone (LH) spikes. $\mathrm{LH}$ is suppressed in higher levels than follicle-stimulating hormone (FSH). Decreased LH levels will inhibit follicle development so as not to ovulate, thereby causing low estrogen and progesterone levels $[10,15]$.

The effects of DMPA mechanisms which suppress ovulation result in a hypoestrogenic environment that will negatively impact the absorption of calcium in the intestine, resulting in the disturbed bone mineral formation [15].
Decreased estradiol levels will stimulate the release of mediators affecting the activity of cells which function as bone breakers, and this will increase the risk of osteopenia and osteoporosis. Estrogen deficiency will increase the activity of the cells that function as bone breakers causing reduced calcium deposits in the bone $[13,19]$.

Cundy et al. research states that when DMPA is given in sufficient doses to induce hypogonadism, the use of MPA can be associated with significant initial trabecular bone loss, which is a consequence of estrogen deficiency [7].

Akinloye et al. stated that injected contraception plays a role in calcium homeostasis which results in an increased effect of calcium mobilization from bone resulting in bone demineralization, which could predispose to osteoporosis [2].

\section{METHODS}

The research design

This was a cross-sectional study. Data were collected at 1 time, where data collection and sampling of blood samples are carried out at the same time. Samples taken were acceptors of DMPA contraception with 2-4 years of use and non-acceptor mothers contraception as control.

Study area

This study was conducted in the Work Area of Lubuk Buaya Health Centre and Andalas Health Centre, Padang city. Examination of FSH, progesterone, and estradiol levels was done in Biomedical Laboratory of Andalas University, Faculty of Medicine by ELISA method, and calcium examination was done in Biochemistry Laboratory of Faculty of Medicine, Andalas University by calcium Arsenazo method.

Inclusion and exclusion criteria

The sample in this study was DMPA contraceptive participants and mothers of non-contraceptive acceptors with a reproductive age of 
20-40 years. For DMPA users with criteria inclusion was already using DMPA contraception for 2-4 years and was normal body mass index (BMI). Criteria for the exclusion of smokers and heavy drinkers suffering from bone disease and using drugs that could affect bone mineral density.

Different from the results of the study Kisok and Hyejin who stated that oral contraceptive use was not related to BMI, household income, drinking alcohol, or regular exercise. in this study, the above criteria were taken into consideration because it could influence hormone and calcium levels to be examined [14].

\section{Sample size determination}

Samples taken must be the same between the two groups in that the results of the study were more significant. The sample calculation formula used is a numerical formula of two independent populations. The total sample in this study was 66 people.

\section{Sampling procedure}

The sample selection was done by consecutive sampling. All subjects who came in sequence and met the inclusion criteria were included in the study until the required number of subjects was met.

\section{Data collection process}

This research was conducted from September 13 to November 2, 2017 in the working area of Lubuk Buaya Padang Health Center, the work area of Padang Andalas Health Center, the Biomedical Laboratory of Andalas University and the Biochemistry Laboratory of Andalas University. This study was conducted on 33 DMPA contraception acceptors and 33 non-KB acceptors who met the inclusion criteria. Taking blood samples are done after the prospective respondent is given an explanation of the background, purpose, and benefits of the study as well as getting written approval from the research subjects.

\section{Variables in the study}

The independent variable in the study was DMPA while the dependent variable was FSH, progesterone, estradiol, and calcium levels.

\section{Data analysis}

Data normality test was carried out using Kolmogorov-Smirnov. To see the difference between dependent and independent variables on normally distributed data, the unpaired $t$-test was performed, whereas the test for non-normally distributed data by Mann-Whitney U-test.

\section{RESULTS}

Based on Table 1 was showed that the mean FSH levels on DMPA acceptor were higher than non-contraception acceptor. The result of statistical test shows that there is significant difference of FSH level between DMPA acceptor and non-acceptor contraception with $\mathrm{p}=0.001$.

Table 1: Difference of FSH levels on DMPA and non-acceptor of contraception

\begin{tabular}{lclc}
\hline Contraception & $\mathbf{n}$ & $\begin{array}{l}\text { Mean } \pm \text { SD } \\
\text { FSH serum (IU/L) }\end{array}$ & $\mathbf{p}$ \\
\hline DMPA & 33 & $7.61 \pm 2.77$ & 0.001 \\
Non-acceptor contraception & 33 & $5.18 \pm 4.48$ & \\
\hline
\end{tabular}

DMPA: Depot medroxyprogesterone acetate, FSH: Follicle-stimulating hormone

Table 2: Difference of progesterone levels on DMPA and non-acceptor of contraceptive

\begin{tabular}{llll}
\hline Contraception & $\mathbf{n}$ & $\begin{array}{l}\text { Mean } \pm \text { SD } \\
\text { progesterone serum } \\
\text { (ng/ml) }\end{array}$ & p \\
\hline DMPA & 33 & $0.91 \pm 1.25$ & 0.001 \\
Non-acceptor contraception & 33 & $6.59 \pm 13.38$ & \\
\hline
\end{tabular}

DMPA: Depot medroxyprogesterone acetate
Based on Table 2 was showed that the mean progesterone levels on DMPA acceptor were lower than non-contraception acceptor. The result of statistical test was showed that there was significant difference of FSH level between DMPA acceptor and non-acceptor contraception with $\mathrm{p}=0.001$.

Based on Table 3 was showed that the mean estradiol levels on DMPA acceptor were lower than non-contraception acceptor. The result of statistical test showed that there was significant difference of FSH level between DMPA acceptor and non-acceptor contraception with $\mathrm{p}=0.001$.

Based on Table 4 was showed that the median calcium levels on DMPA acceptor were lower than non-contraception acceptor. The result of statistical test was showed that there was significant difference of FSH level between DMPA acceptor and non-acceptor contraception with $\mathrm{p}=0.001$.

\section{DISCUSSION}

Differences of FSH levels on KB DMPA acceptor and non-KB acceptor

Table 1 shows that the mean FSH levels were higher in DMPA KB acceptor that is $7.61 \pm 2.77 \mathrm{IU} / \mathrm{L}$ than the mean of FSH content on non-acceptor of KB was $5.18 \pm 4.48 \mathrm{IU} / \mathrm{L}$. FSH statistical test results obtained $\mathrm{p}=0.001$; then, it could be concluded that there was a significant difference between KB DMPA acceptor and non-acceptor KB.

The use of DMPA progesterone would be work by decreasing GnRH pulsation produced in the hypothalamus, thus reducing $\mathrm{LH}$ release from the anterior pituitary. DMPA in the blood circulation will inhibit LH spikes in midcycle, but LH and FSH remain at the same level in the luteal phase $[15,18]$

In this research, the mean FSH levels were higher in the group using DMPA KB which was $7.61 \pm 2.77 \mathrm{IU} / \mathrm{L}$ compared with those not using KB that was 5.18 $\pm 4.48 \mathrm{IU} / \mathrm{L}$. Although DMPA could effectively suppress LH spikes, it could not be completely suppressed FSH so that the follicle continues to be stimulated to make estrogen. Estradiol would then stimulate the anterior pituitary to release FSH (positive feedback) so that the FSH level increases or remains at the same level in the luteal phase.

Differences in progesterone levels in KB DMPA and non-KB acceptor

The mean progesterone level on KB DMPA acceptor was $0.91 \pm 1.25 \mathrm{ng} / \mathrm{ml}$ while mean progesterone level in non-acceptor of family planning was $6.59 \pm 13.38 \mathrm{ng} / \mathrm{ml}$. The result of statistical test of progesterone obtained $p=0.001$, hence, could be concluded that there was significant difference between family planning DMPA acceptor and contraception acceptor.

Table 3: Difference of estradiol levels on DMPA and non-acceptor of contraceptive

\begin{tabular}{llll}
\hline Contraception & $\mathbf{n}$ & $\begin{array}{l}\text { Rerata } \pm \text { SD } \\
\text { estradiol serum } \\
\mathbf{( p g / m l )}\end{array}$ & $\mathbf{p}$ \\
\hline DMPA & 33 & $87.49 \pm 45.00$ & 0.001 \\
Non-acceptor contraception & 33 & $137.56 \pm 60.33$ & \\
\hline
\end{tabular}

DMPA: Depot medroxyprogesterone acetate

Table 4: Difference of calcium levels on DMPA and non-acceptor of contraceptive

\begin{tabular}{llll}
\hline Contraception & $\mathbf{n}$ & $\begin{array}{l}\text { Median } \\
\text { calcium serum } \\
\text { (mg/d) }\end{array}$ & $\mathbf{p}$ \\
\hline DMPA & 33 & 8.44 & 0.001 \\
Non-acceptor contraception & 33 & 10.09 & \\
\hline
\end{tabular}

DMPA: Depot medroxyprogesterone acetate 
The mean progesterone levels were lower in contraception DMPA acceptor mothers compared with non-acceptor mothers. This was in that DMPA suppresses preovulatory LH secretion in that ovulation will be suppressed at least for 14 weeks. Inhibited ovulation would be kept low progesterone levels in the blood $(<4 \mathrm{ng} / \mathrm{ml})$ for several months after injection. When the level decreases $(<0.1 \mathrm{ng} / \mathrm{ml})$, then the ovulation may be possible [18].

The research conducted by Clark et al., on the magnitude and variability of estradiol and progesterone concentrations in women using DMPA, showed an average daily concentration of progesterone $0.14-1.1 \mathrm{ng} / \mathrm{ml}$ with a mean of $0.40 \pm 0.19 \mathrm{ng} / \mathrm{ml}[6]$.

\section{The differences of estradiol levels in KB DMPA acceptor and non- acceptor of KB}

The mean estradiol content was lower in the mother of KB DMPA acceptor compared with the non-acceptor mother of KB. This was due to the use of DMPA contains high levels of progesterone which can inhibit the development of follicles and cause a decrease in estradiol levels. Long-term use of DMPA type KB may also cause serum estradiol levels to be lower or in the follicular phase duration $[8,15]$.

The results of this research were in line with Pamuji et al., which examined the serum estrogen level of 70 women who used DMPA. All study subjects showed low concentrations of estradiol with an average concentration of $<150 \mathrm{pg} / \mathrm{ml}$; the results suggest that there was a correlation between the length of the use of DMPA and estradiol levels [16].

The results above were also in line with the Razali research, which states that DMPA family users within $1-2$ years period obtained an average blood estradiol level of $78.69 \pm 29.76 \mathrm{pg} / \mathrm{ml}$ and the used within $3-5$ years period obtained an average level of $54.23 \pm 21.07 \mathrm{pg} / \mathrm{ml}$. The decrease in estradiol levels was limited in the follicular phase, but it was still lower than this study where the mean estradiol blood level was $87.494 \pm 45.004 \mathrm{pg} / \mathrm{ml}[17]$.

\section{The differences of calcium levels on KB DMPA acceptor and non-KB} acceptor

The effects of DMPA mechanisms that suppress ovulation lead to a hypoestrogenic environment that will negatively impact the absorption of calcium in the intestine so that bone mineral formation is impaired. Estrogens are essential for maintaining bone strength that regulates transporting calcium into bone. Without adequate estrogen, the bone loses calcium which is the most important component of bone [15].

Estrogen hormone deficiency can also increase calcium removal through the kidneys and also induce hyperparathyroidism which causes loss of bone mass. Without adequate levels of estrogen, bones are unable to absorb the right amount of calcium for bone repair, increasing bone mass. Decreased estrogen could be also lead to increased calcium excretion through the kidneys $[1,9]$.

Akinloye et al. indicated that there is an increase in calcium resorption occurred in the use of oral contraceptives and injections. This contraception plays a role in calcium homeostasis which results in an increased effect of calcium mobilization from bone resulting in bone demineralization, which can predispose to osteoporosis [2].

The results of this research found low calcium levels in contraception DMPA acceptor women, whereas normal serum calcium level was $8.9-10.5 \mathrm{mg} / \mathrm{dl}$. Calcium levels $<8.9 \mathrm{mg} / \mathrm{dl}$ were found in 29 women of DMPA acceptor women, and only four DMPA users were within normal limits. In the non-acceptors group of $\mathrm{KB}$, calcium levels $<8.9 \mathrm{mg} / \mathrm{dl}$ were found in as many as six people, whereas in the normal limit was found as many as 22 people and the other five people were found that it was valued above the normal calcium level.

\section{Study limitations}

Limitations in this study were that the researchers did not equalize the time and blood sampling interval after DMPA injection.

\section{Ethical considerations}

Ethical approval was granted by the Ethical Committee of Medicine, Andalas University of Indonesia No. 297/KEP/FK/2017.

\section{CONCLUSION AND RECOMMENDATION}

Long-term use of DMPA contraception could be affect the levels of FSH, progesterone, estradiol, and calcium in the blood. It was suggested that further studies are expected to consider the time and interval for taking blood samples after DMPA injection and to examine the relationship between estradiol levels and calcium in DMPA acceptor mothers.

\section{ACKNOWLEDGMENTS}

Authors thank all respondents for their willingness and consent to participate in the research. We also acknowledge and thank all research assistants for their tireless efforts without which this research work would not have been completed.

\section{AUTHORS' CONTRIBUTION}

NS, RSR, and Y conceived of the research. NS, RSR, and Y designed the survey instruments. NS collected and managed the survey data. NS, RSR, and Y led the analysis and wrote the preliminary text of the paper and all authors reviewed and edited the text and approved the final manuscript.

\section{CONFLICTS OF INTEREST}

All authors declare that they have no conflicts of interest.

\section{REFERENCES}

1. Van Abel M, Hoenderop JG, Dardenne O, St Arnaud R, Van Os CH, Van Leeuwen HJ, et al. 1,25-dihydroxyvitamin $\mathrm{D}(3)$-independent stimulatory effect of estrogen on the expression of $\mathrm{ECaC} 1$ in the kidney. J Am Soc Nephrol 2002;13:2102-9.

2. Akinloye O, Adebayo TO, Oguntibeju OO, Oparinde DP, Ogunyemi EO. Effects of contraceptives on serum trace elements, calcium and phosphorus levels. West Indian Med J 2011;60:308-15.

3. Statistik BP. Statistik 70 Tahun Indonesia Merdeka. Jakarta: CV. Dharma Putra; 2015.

4. BAPPENAS. Pemanfaatan DAK KB Dalam Pencapaian Pembangunan Nasional Bidang KKBPK Serta Arah Kebijakan DAK KB TA 2015 dan Rancangan TA 2016. Jakarta: Kementerian PPN/Bappenas; 2016.

5. Becker KL. Principal and Practice of Endocrinology and Metabolism. Philadelphia, PA: Lippincott Williams and Wilkins; 2001.

6. Clark MK, Sowers M, Levy BT, Tenhundfeld P. Magnitude and variability of sequential estradiol and progesterone concentrations in women using depot medroxyprogesterone acetate for contraception. Fertil Steril 2001;75:871-7.

7. Cundy T, Farquhar CM, Cornish J, Reid IR. Short-term effects of high dose oral medroxyprogesterone acetate on bone density in premenopausal women. J Clin Endocrinol Metab 1996;81:1014-7.

8. Dillis CL. Change in mammographic breast density associated with the use of Depo-Provera. Breast J 2003;9:312-5.

9. Djuwantono T, Bayuaji H, Permadi W. Step by Step Penanganan Kelainan Endokrinologi Reproduksi Dan Fertilitas Dalam Praktik Sehar-Hari. Bandung: CV. Sagung Seto; 2012.

10. Fritz MA, Speroff L. Clinical Gynecology Endocrinology and Infertility. Philadelphia, PA: Lippincott Williams and Wilkins; 2011.

11. Ghorab MK, Makram TS. Industrialization of medroxy progesterone acetate in prolonged parental suspension (Part I). Int J Pharm Pharm Sci 2014;7:364-9.

12. Kementerian Kesehatan Republik Indonesia. Situasidan Analisis Keluarga Berencana. Jakarta: Kemenkes RI; 2014.

13. Khosla S, Oursler MJ, Monroe DG. Estrogen and the skeleton. Trends Endocrinol Metab 2012;23:576-81.

14. Kisok K, Hyejin P. Demographic factors associated with oral contraceptive use in Korea women. Int $\mathrm{J}$ Pharm Pharm Sci 2016;8:299-301.

15. Nelson AL. DMPA battered and bruised but still needed and used in the USA. Obtest Gynecol 2010;5:673-86.

16. Pamuji, ES, Hakimi DD. Association between bleeding pattern and estradiol level of depot medroxy preogesterone acetate users. Berita Kedokteran Masyarakat 2008;24:51-7. 
17. Razali RR. Kadar Estradiol Serum Pada Pemakaian KB DMPA 1 Tahun Dan 3 Tahun. Tesis. FK USU; 2008.

18. Courtney AS, Kurt B. Contraception Dalam Yen and Jaffe's Reproductive Endoctinology: Physiology, Pathophysiology and Clinical Management. Philadelphia, PA: Elsevier; 2009.
19. Spevack E. The long term health implications of Depo-Provera. Integr Med 2013;2:1

20. Strauss JF, Barbieri R. Reproductive and Endocrinology, Physiology, Pathophysiology and Clinical Management. Philadelphia, PA: Elsevier; 2014. 